Hidayatul Astar: Konstruksi Sepadan dan Tak Sepadan antara Larik...

\title{
KONSTRUKSI SEPADAN DAN TAK SEPADAN ANTARA LARIK SAMPIRAN DAN LARIK ISI SEBUAH PANTUN
}

\author{
Commensurate and Incommensurate Construction between \\ Sampiran and Content Lines of a Pantun \\ Hidayatul Astar \\ Pusat Pengembangan dan Pelindungan \\ Badan Pengembangan dan Pembinaan Bahasa \\ Jalan Daksinapati Barat IV Rawamangun, Jakarta Timur \\ Posel: hidayatul.astar@yahoo.co.id
}

Naskah diterima: 12 Mei 2020, disetujui: 6 Juni 2020, revisi akhir: 24 Juni 2020

\begin{abstract}
Abstrak
Pantun merupakan salah satu puisi lama Melayu yang memiliki ciri keindahan atau keteraturan bahasanya. Banyak tulisan yang telah membahas hal tersebut, tetapi belum ada yang membahas secara lebih spesifik dari sisi konstruksi sepadan dan tak sepadan antara larik sampiran pertama (S-1) dan isi pertama (I-1) dan antara larik sampiran kedua (S-2) dan isi kedua (I-2). Metode yang digunakan adalah deskriptif kualitatif. Konsepsi tentang linguistik struktural hubungan sintagmatik yang dikemukan Robins (1992) dan konsepsi Alwi et.al. (2017) tentang unsur kalimat, fungsi sintaksis, susunan unsur, dan jenis kalimat menjadi acuan analisis data. Hasil penelitian menunjukkan bahwa ada tiga bentuk konstruksi pantun. Dari 100 pantun yang diteliti, 39 pantun atau 39\% berkonstruksi sepadan penuh, 41 atau $41 \%$ berkonstruksi sepadan sebagian, dan 20 atau $20 \%$ berkonstruksi tak sepadan. Ketiga kategori konstruksi tersebut ditandai oleh ciri-ciri tertentu. Pantun kategori pertama ditandai oleh jumlah unsur, jumlah kata, fungsi sintaksis, susunan unsur, dan jenis kalimat yang sama; pantun kategori kedua ditandai oleh kesamaan dan ketaksamaan kelima aspek tersebut; pantun kategori ketiga ditandai oleh jumlah unsur dan fungsi sintaksis yang tak sama dan susunan unsur dan jenis kalimat yang sama dan tak sama. Pantun berkonstruksi sepadan lebih indah atau lebih teratur bahasanya daripada yang tak sepadan dan dapat menjadi acuan ketika berpantun.
\end{abstract}

Kata kunci: konstruksi sepadan, pantun, sampiran, isi

\begin{abstract}
Pantun is one of the old Malay poems which has a characteristic of regularity of language. The beauty of pantun language has been discussed in many writings, but no one has discussed more specifically in term of its construction. This article discusses the form construction between the first sampiran lines (S-1) and the first content (I-1) and between the second sampiran lines (S-2) and the second content (I-2) of a pantun. The method used is descriptive qualitative method. A reference for data analysis is followed the conception of structural linguistics of syntagmatic relations proposed by Robins (1992) and Alwi et.al. (2017) specially syntactic elements, syntactic functions, sequence of elements, and type of sentence. The results of this study to show that there are three construction of pantun. Out of 100 pantun studied, 39 or $39 \%$ had full commensurate construction, 41 or $41 \%$ had partially commensurate construction, and 20 or $20 \%$ had incommensurate construction. All three construction kategories are marked by certain charecteristics. The first pantun kategories is characterized by the number of elements, number of words, syntactic functions, sequence of elements, and type of sentence of the same. The second pantun kategories is characterized by all five aspects of the same and not. The third pantun kategories is characterized by the number of elements and syntactic functions that are not the same and the sequence of elements and type of sentence of the same and not. Pantuns with commensurate constructions are more beautiful than pantuns that incommensurate and can be reference.
\end{abstract}

Keywords: commensurate construction, pantun, sampiran, content 
Hidayatul Astar: Konstruksi Sepadan dan Tak Sepadan antara Larik...

\section{PENDAHULUAN}

Pantun merupakan salah satu bentuk puisi Melayu lama selain syair, seloka, mantra, dan gurindam. Dibandingkan dengan tiga bentuk puisi lama lainnya, pantun lebih populer sehingga dikenal luas, khususnya di daerah yang berbasis bahasa Melayu seperti di Riau, Sumatera Barat (Minang), dan Jakarta (Betawi). Ini disebabkan pada zaman dahulu masyarakat Melayu berpantun dalam percakapan sehari-hari. Sampai saat ini pun pantun sering digunakan oleh, antara lain, tokoh adat, tokoh politik, tokoh agama, dan pejabat pemerintahan dalam acara-acara tertentu baik resmi maupun tak resmi.

Konsep pantun menitikberatkan pada susunan kata yang teratur sebagaimana disebutkan dalam pengertian kata pantun tersebut dalam beberapa bahasa di nusantara. Dalam bahasa Pampanga dikenal kata tuntun yang berarti 'teratur', dalam bahasa Tagalog tonton yang berarti 'bercakap atau berkata secara teratur, dalam bahasa Jawa Kuno, tuntun, atuntun, dan matuntun yang berarti 'benang', 'teratur', dan 'memimpin', dan pantun dalam bahasa Toba yang berarti 'kesopanan, kehormatan (Liaw, 2013: 442 ). Makna kata pantun yang diberikan ini semuanya tertuju kepada ucapan atau tulisan yang teratur dan sopan.

Makna tersebut tentu didasari atas bentuk konstruksi dari pantun-pantun yang telah tercipta atau yang ada di wilayah tersebut. Secara tidak langsung definisi itu memberi arahan penciptaan sebuah pantun yang baik, yaitu keteraturan bahasanya dan berasaskan kesopanan atau kehalusan budi. Ketentuan seperti itu dapat diperhatikan dalam salah satu pantun Melayu klasik berikut. Pantun ini tercipta untuk mewakili sebuah fenomena kehidupan masyarakat Melayu atau masyarakat umum yang terkait dengan utang piutang.

Patah lancang kita sadaikan

Supaya sampan tidak melintang

Petuah orang kita sampaikan

Supaya badan tidak berhutang (PM)

Ketika pantun tersebut dituturkan atau dibaca terdengar atau terasakan keindahan bahasanya atau keteraturan susunan katanya, khususnya antara larik sampiran pertama (S-1) dan larik isi pertama (I-1) dan antara larik sampiran kedua (S-2) dan larik isi kedua (I-2) atau antarlarik ganjil dan genap. Keindahan bahasa itu ditandai oleh kesepadanan bunyi yang berupa kesamaan kata dan bunyi tertentu pada posisi di awal, tengah, dan akhir larik. Selain itu, konstruksi antara larik sampiran dan isinya juga memperlihatkan kesepadanan jumlah unsur, yaitu samasama dua unsur per larik, tiap unsur selalu terdiri atas dua kata, menduduki fungsi sintaksis yang sama, susunan unsur, jenis kalimat dan yang sama pula sebagaimana terlihat berikut ini.

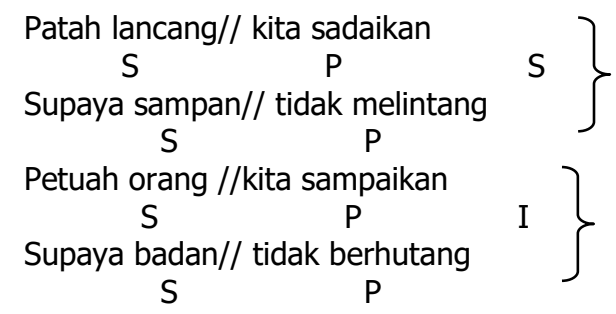

Ciptaan pantun seperti itu menarik untuk diteliti dari berbagai aspek kebahasaan. Pantun yang begitu banyak tercipta apakah selalu demikian kontruksinya. Untuk itu, penelitian ini mempermasalahkan konstruksi setiap pantun yang tercipta, khususnya konstruksi antara larik S-1 dan larik I-1 dan antara larik S-2 dan larik I-2 atau antarlarik gajil dan antarlarik genap sebuah pantun.

Hasil penelitian ini berguna untuk melengkapi penelitian kebahasaan pantun yang telah dilakukan oleh beberapa peneliti terdahulu. Hasil penelitian ini juga dapat menjadi acuan bagi para siswa, guru, peneliti, pemantun, atau masyarakat umum ketika akan menyusun pantun atau berpantun.

Berdasarkan tinjauan kepustakaan, penelitian terhadap konstruksi pantun telah dilakukan oleh Astar (2019), tetapi belum sampai kepada pemilahan konstruksi yang sepadan dan tak sepadan secara lebih spesifik dan mendalam dari sisi jumlah unsur, fungsi sintaksis, susunan unsurnya, dan jenis kalimatnya. Beberapa peneliti lain, antara lain, Wiana (2010), Andriani dan Amalia (2012), dan Agustina (2016) juga telah meneliti pantun. Kajian yang mereka lakukan berbeda-beda fokusnya. 
Hidayatul Astar: Konstruksi Sepadan dan Tak Sepadan antara Larik...

Wiana (2010) mengkaji pantun dari sisi kajian fungsional lingusitik, khususnya tema dan rema. Ada tiga tema yang dikemukakannya, yaitu tema tekstual, topikal, dan interpersonal berdasarkan data pantun dalam buku Pantun dan Pepatah Melayu. Sementara itu, Agustina melihat pilihan kata pantun dari sisi makna denotasi dan konotasi, konkret, figuratif, dan rima. Data pantun yang ditelitinya terdapat dalam buku Pantun dan Budaya Adat Istiadat Tata Cara Perkawinan Adat Kabupaten Sambas.

Selanjutnya, Andriani dan Amalia (2016) mengkaji pantun dari aspek jenis-jenis pantun Melayu, fungsinya sebagai identitas, dan perannya sebagai media pendidikan dalam kehidupan masyarakat. Wiana, Agustina, dan Astar mengkaji pantun berdasarkan aspek kebahasaan, sedangkan Andriani dan Amalia mengkajinya dari aspek kehidupan masyarakat Melayu secara historis dan antropologis.

Penelitian terhadap kontruksi pantun ini menggunakan kerangka berpikir linguistik struktural hubungan sintagmatik. Konsepsi ini mengacu pada hubungan antara elemen-elemen yang membentuk struktur berurutan pada tataran tertentu (Robins, 1992: 57). Larik pantun dalam hal ini dikategorikan sebagai sebuah satuan bahasa yang dibangun oleh beberapa kata dan dapat dipilah-pilah atas unsurunsurnya. Sehubungan dengan hal itu, Alwi et al. (2017: 407--548) telah mengemukakan konsep unsur kalimat, fungsi sintaksis, dan urutan unsur, dan jenis kalimat. Unsur kalimat terbagi lima, yaitu subjek $(S)$, predikat $(P)$, objek $(O)$, pelengkap (Pel.), dan keterangan (K). Kelima unsur kalimat itu tidak selalu ada dalam sebuah kalimat dasar karena tergantung pada konteks makna atau informasi yang ingin disampaikan seorang penulis atau pembicara. Susunan unsur dalam konstruksi kalimat menempatkan $S$ dan $P$ sebagai patokan sehingga hanya dua jenis susunan, yaitu susunan biasa S-P dan susunan inversi P-S. Jenis kalimat pada dasarnya hanya terbagi dua, yaitu kalimat sederhana atau tunggal dan kalimat majemuk atau kompleks. Dalam penelitian ini digunakan konsepsi Alwi et al. (2017) sebagai bentuk perwujudan yang lebih konkret terhadap konsepsi yang dikemukan Robins (1992).

Pantun sebagai salah satu genre sastra memiliki ciri-ciri umum. Harun Mat Piah (1989) dan Mohd. Yusof Md. Nor dan Abd. Rahman Kaeh (1985) mengungkapkan ciriciri pantun Melayu sebagai berikut (Rahman, 2016: 2-3). Pantun selalu berangkap; setiap rangkap terdiri kerat atau baris; jumlah suku kata setiap baris delapan sampai dua belas; ada baris pembayang (sampiran) dan maksud (isi); skema rima akhir baris a, b, a, b; setiap rangkap pan-tun memiliki kesatuan pikiran yang lengkap dan sempurna; pantun memiliki lambang atau simbol yang sesuai dengan norma dan nilai (tata susila) masyarakat setempat. Ciri pantun tersebut menjadi acuan terhadap ciptaan pantun yang diteliti.

Dalam kajian bahasa tradisi lisan dikenal isitilah formulaic expression (ungkapanungkapan baku) seperti yang telah dikemukakan oleh Pudentia MPSS (2000) dalam Setyawati (2004: 252) dan Gayatri (2010: 81-86) dalam tulisannya tentang ronggeng Pasaman. Pudentia mencontohkan kosep formula dalam dialog antar tokoh cerita Melayu. Ungkapan antar tokoh ada yang sama atau diucapkan lagi oleh tokoh lain dan dianggap sebagai formula dalam cerita tersebut. Sementara itu, Gayatri memberi contoh konsep formula dalam teks pantun ronggeng Pasaman berupa pengulangan kata, frasa, klausa, atau larik secara berkali-kali baik dalam satu bait maupun antarbait. Dalam penelitian ini ini konsep formula yang dicontohkan dua peneliti tradisi lisan tersebut juga menjadi acuan.

\section{METODE PENELITIAN}

Penelitian ini menggunakan metode deskriptif kualitatif. Pantun yang diteliti bersumber dari buku dan unduhan internet. Ada seratus pantun yang diteliti. Dari 100 pantun itu, sebanyak 34 merupakan pantun Melayu Bangka (PMB) yang terdapat dalam buku Bahasa Pantun Bangka, 55 merupakan pantun Melayu (PM) unduhan internet, dan 11 pantun pejabat dan penceramah (PP) unduhan internet. 
Hidayatul Astar: Konstruksi Sepadan dan Tak Sepadan antara Larik...

Pembagian tiga sumber ini berguna sebagai bahan bahan perbandingan. Setiap larik sampiran dan isi setiap pantun diidentifikasi jumlah unsurnya dengan cara memberi batasan memakai dua garis miring $(/ /)$. Setelah teridentifikasi, pantun tersebut dikelompokkan menjadi tiga, yaitu (1) pantun berkonstruksi sepadan penuh dengan ketentuan jumlah unsur antara larik S-1 dan I-1 dan antar larik S-2 dan I-2 sama, (2) pantun berkonstruksi sepadan sebagian dengan ketentuan salah satu larik sampiran memiliki jumlah jumlah unsur yang tidak sama dengan salah satu larik isi, dan (3) pantun berkonstruksi tak sepadan dengan ketentuan kedua larik sampiran memiliki jumlah unsur yang tidak sama dengan larik isi.

Pantun kategori (1) dan (2) diidentifikasi lagi dari sisi jumlah kata, fungsi sintaksis, susunan unsur, dan jenis kalimatnya, sedangkan pantun kategori (3) diidentifikasi lagi dari sisi fungsi sintaksis, susunan unsur, dan jenis kalimatnya. Hasil klasisifikasi dan identifikasi tersebut menjadi dasar analisis atau ulasan terhadap kesepadanan dan ketaksepadan konstruksi antara larik sampiran dan isi pantun. Berdasarkan hasil analisis tersebut, dilakukan pembahasan dan penyimpulan.

\section{HASIL DAN PEMBAHASAN}

\subsection{Pengantar}

Dari 100 pantun yang diteliti, berdasarkan jumlah unsur tiap larik pantun, konstruksi sepadan penuh terdapat dalam 39 pantun atau $39 \%$, konstruksi sepadan sebagian terdapat dalam 41 atau $41 \%$ pantun, dan konstruksi tak sepadan terdapat dalam 20 atau $20 \%$ pantun. Data itu menunjukkan bahwa larik sampiran dan isi pantun yang tercipta lebih banyak berkonstruksi yang sepadan sebagian daripada yang sepadan penuh dan tak sepadan. Ketiga kategori konstruksi itu ditandai oleh kesepadan dan ketaksepadan jumlah kata per unsur, fungsi sintaksis, susunan, dan jenis kalimatnya.

\subsection{Konstruksi Sepadan Penuh}

Pantun (1--5) berikut ini merupakan pantun berkonstruksi sepadan penuh karena jumlah unsur antara larik S-1 dan I-
1 dan antara larik S-2 dan I-2 selalu sama. Kelima pantun ini juga memperlihatkan kesepadanan jumlah kata per unsur, fungsi sintaksis, susunan unsur, jenis kalimatnya. Bahkan kesepadannya terlihat pula antarsampiran ( S-1 dan S-2) dan antarisi (I-1 dan I-2) seperti pada pantun (1)--(3).

Pantun (1) berikut sama-sama terbagi atas dua unsur setiap lariknya. Unsur pertama tiap larik sama-sama hanya terdiri atas satu kata; unsur kedua S-1 dan I-1 sama-sama terdiri atas tiga kata dan unsur kedua S-2 dan I-2 sama-sama terdiri atas dua kata.

(1) Tuailah //padi antara masak

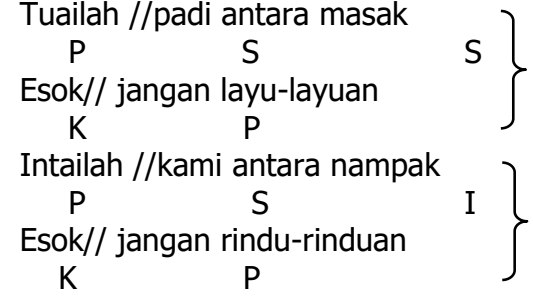

(PM)

Dua unsur larik pantun (1) tersebut ditandai pula oleh kesepadanan fungsi sintaksis dan susunan unsurnya. Larik S-1 dan I-1 sama-sama menduduki fungsi predikat (P) dan subjek (S) dan larik S-2 dan I-2 sama-sama menduduki fungsi keterangan $(K)$ dan $P$; susunan unsur larik S-1 dan I-1 sama-sama dalam susunan inversi dan susunan unsur larik S-2 dan I-2 sama-sama dalam susunan biasa. Subjek yang diimplisitkan dalam S-2 dan I-2 mendahului predikat: esok (kita)....

Larik sampiran dan larik isi pantun tersebut merupakan sama-sama satu kalimat yang berjenis sama, yaitu samasama sebuah kalimat majemuk bertingkat yang ditandai oleh konjungsi supaya/agar yang diimplisitkan. Dua sampiran dan isi pantun tersebut dapat diubah menjadi dua kalimat berikut.

a.Tuailah padi antara masak supaya esok jangan layu-layuan.

b. Intailah kami antara nampak supaya esok jangan rindu-rinduan.

Pantun (2) berikut juga sama-sama terbagi atas dua unsur setiap lariknya. Unsur pertama larik S-1 dan I-1 samasama terdiri atas satu kata dan unsur pertama S-2 dan I-2 sama-sama terbagi atas dua unsur. Baik unsur kedua larik S-1 
Hidayatul Astar: Konstruksi Sepadan dan Tak Sepadan antara Larik...

dan I-1 maupun unsur kedua larik S-2 dan I-2 sama-sama terbagi atas tiga unsur.

(2) Kalau ada// jarum yang patah

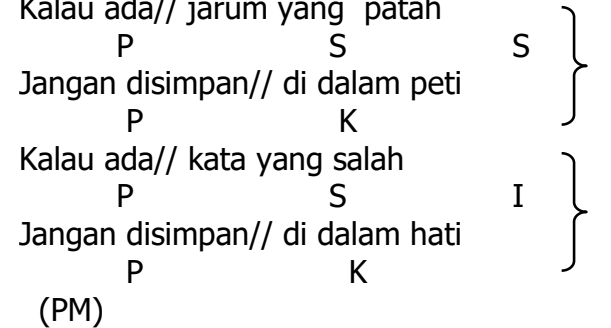

Dua unsur larik S-1 dan I-1 dan S-2 dan I-2 pantun (2) tersebut menduduki fungsi yang sama seperti dua unsur pantun (1). Yang berbeda hanya susunan $\mathrm{K}$ dan $\mathrm{P}$ menjadi $P$ dan $K$. Susunan unsur larik $S-1$ dan I-1 dan susunan unsur larik S-2 dan I2 sama-sama dalam susunan inversi. Subjek yang diimplisitkan dalam S-2 dan I2 terletak setelah predikat: jangan disimpan (jarum yang patah)..., jangan disimpan (kata yang salah)....

Larik sampiran dan larik isi pantun tersebut juga merupakan sama-sama satu kalimat yang berjenis sama, yaitu samasama sebuah kalimat majemuk bertingkat yang ditandai oleh konjungsi kalau. Dua sampiran dan isi pantun tersebut dapat diubah menjadi dua kalimat berikut.

a. Kalau ada jarum yang patah, jangan disimpan di dalam peti.

b. Kalau ada kata yang salah, jangan isimpan di dalam hati

Konstruksi pantun (3) juga sama dengan pantun (1) dan (2) karena juga sama-sama terbagi atas dua unsur setiap lariknya. Akan tetapi, ada perbedaan dari sisi jumlah klausa. Jika pantun (1) dan (2) semua lariknya dalam satu klausa, tidak demikian dengan pantun (3) karena larik genapnya terdiri atas dua klausa. Baik unsur pertama dan kedua larik

S-1 dan I-1 maupun unsur pertama dan kedua larik S-2 dan I-2 sama-sama terdiri atas dua kata.

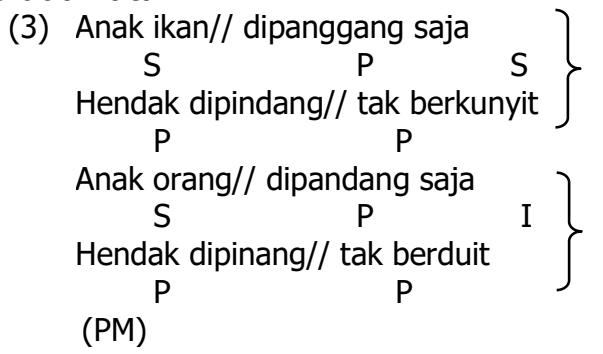

Dua unsur larik S-1 dan I-1 pantun (3) menduduki fungsi yang sama, yaitu $S$ dan $P$ seperti dua unsur pantun (1) dan (2), tetapi posisinya berbeda. Dua unsur $\mathrm{S}-2$ dan I-2 pantun (3) menduduki fungsi sintaksis berbeda dengan dua unsur pantun (1) dan (2). Dua unsurnya menduduki fungsi $P$ dan $P$ karena terdiri atas dua klausa. Susunan unsur larik S-1 dan I-1 dan unsur larik S-2 dan I-2 samasama dalam susunan biasa. Subjek yang diimplisitkan dalam S-2 dan I-2 mendahului predikat: (anak ikan) hendak dipindang; (anak orang) hendak dipinang; (kami) tak berduit.

Larik sampiran dan larik isi pantun tersebut sama-sama berjenis kalimat yang sama. Baik S-1 dan S-1 maupun I-1 dan I2 merupakan kalimat tunggal dan kalimat majemuk bertingkat. Pembentukan larik kedua didahului oleh pertanyaan Mengapa anak ikan dipanggang saja? (S-1); Mengapa anak orang dipandang saja? (I1). Jawaban dari pertanyaan itu adalah Karena ketika ikan hendak dipindang, kami tak berkunyit (S-2); Karena ketika anak orang hendak dipinang, kami tak berduit (I-2).

Dua sampiran dan isi pantun tersebut dapat diubah menjadi dua kalimat berikut.

\section{a. Anak ikan dipanggang saja karena ketika hendak dipindang, kami tak berkunyit. \\ b. Anak orang dipandang saja karena ketika hendak dipinang, kami tak berduit.}

Jika larik S-1 dan I-1 dan S-2 dan I-2 pantun (1)-(3) sama-sama terbagi atas dua unsur, larik S-1 dan I-1 dan S-2 dan I2 pantun (4) tidak demikian. Larik S-1 dan I-1 terbagi atas dua unsur dalam satu klausa, sedangkan larik S-2 dan I-2 terbagi atas tiga unsur dalam dua klausa. Unsur pertama dan kedua larik S-1 dan I-1 samasama terdiri atas dua kata; unsur pertama, kedua, dan ketiga larik S-2 dan I-2 samasama terdiri atas dua, satu, dan satu kata.

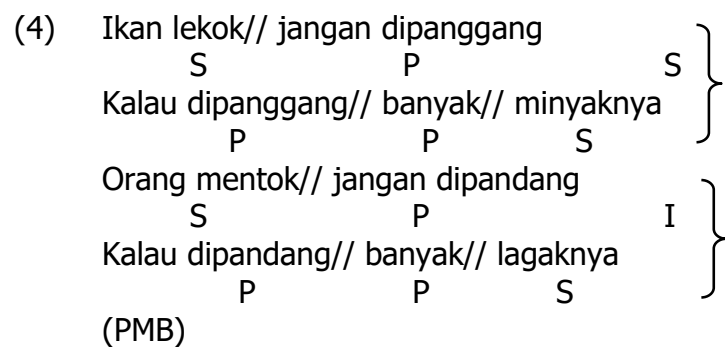


Hidayatul Astar: Konstruksi Sepadan dan Tak Sepadan antara Larik...

Dua dan tiga unsur pantun tersebut menduduki fungsi yang sama, yaitu $S$ dan P; P, P, dan S. Berdasarkan posisi fungsi sintaksisnya, susunan unsur larik S-1 dan I-1 sama-sama dalam susunan biasa dan unsur S-2 dan I-2 dalam susunan biasa dan inversi dengan asumsi subjek yang diimplisitkan mendahului predikat: kalau (ikan lekok) dipanggang...; kalau (orang mentok) dipandang....

Dua larik sampiran dan dua larik isi pantun tersebut juga sepadan jenis kalimatnya dan proses pembentukannya sama dengan proses pembentukan sampiran dan isi pantun (3), yaitu dengan mengajukan pertanyaan Mengapa ikan lekok jangan dipanggang? (S-1); Mengapa orang Mentok jangan dipandang? (I-1). Jawaban dari pertanyaan itu adalah Kalau ikan lekok dipanggang, banyak minyaknya (S-2); Kalau orang Mentok dipandang, banyak lagaknya. Dua sampiran dan isi pantun tersebut dapat diubah menjadi dua kalimat berikut.

a. Ikan lekok jangan dipanggang karena kalau dipanggang, banyak minyaknya.

b. Orang Mentok jangan dipandang karena kalau dipandang, banyak lagaknya.

Jika dua dan tiga unsur pantun (4) terdapat dalam larik S-1 dan I-1 dan larik S-2 dan I-2, dua dan tiga unsur pantun (5) terdapat dalam larik S-2 dan I-2 dan larik S-1 dan I-1. Unsur pertama, kedua, dan ketiga larik S-1 dan I-1 sama-sama terdiri atas satu, dua, dan satu kata; unsur pertama dan kedua larik S-2 dan I-2 samasama terdiri atas dua kata.

(5) Kalau tahu// peria tu// pahit

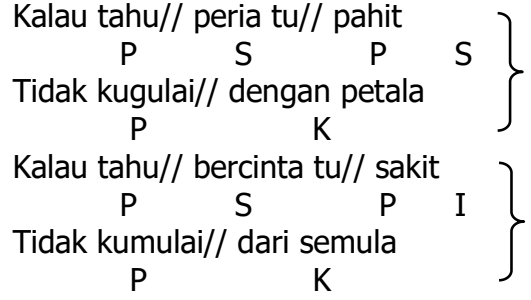
(PM)

Tiga dan dua unsur dalam larik ganjil dan genap pantun tersebut menduduki fungsi yang sama, yaitu P, S, dan P; P dan K. Berdasarkan posisi fungsi sintaksisnya, baik susunan unsur larik sampiran maupun larik isi sama-sama dalam susunan biasa dan inversi. Subjek yang diimplisitkan dalam larik S-1 dan I-1 mendahului predikat, kalau (aku) tahu...; (peria itu) tidak...; bercinta itu) tidak....

Larik sampiran dan larik isi pantun tersebut juga merupakan kalimat berjenis sama, yaitu kalimat kalimat majemuk bertingkat yang ditandai oleh konjungsi kalau. Konstruksinya sama dengan konstruksi pantun (2). Dua sampiran dan isi pantun tersebut dapat diubah menjadi dua kalimat berikut.

a. Kalau tahu peria tu pahit, tak kugulai degan petala.

b. Kalau tahu bercinta tu sakit, tak kumulai dari semula.

Lima pantun berkonstruksi sepadan penuh tersebut ditandai oleh bentuk pengulangan kata dan frasa sebagai penanda adanya formula seperti dalam ronggeng Pasaman yang dibahas Gayatri (2010). Kata dan frasa yang diulang terdapat di awal, di tengah, dan di akhir larik. Pengulangan kata dan frasa itu berkontribusi untuk menyepadankan struktur dan jenis kalimat antarsampiran dan antarisi. Ini dibuktikan oleh setiap larik sampiran dan isi dapat diubah ke dalam dalam satu konstruksi kalimat yang berstruktur dan berjenis kalimat yang sama.

Terbentuknya konstruksi yang sepadan tidak hanya ditentukan oleh pengulangan kata, tetapi juga oleh pengulangan dalam batas suku kata yang berupa imbuhan, seperti terdapat dalam kata seperti tuai/ah, intai/ah, layu-layuan, rindu-rinduan, lagaknya, minyaknya, kugulai, kumulai, dipanggang, dan dipandang. Jika imbuhannya tidak sama dapat menyebabkan adanya peru-bahan struktur dan pola sebuah konstruksi kalimat. Misalnya kata dipandang dan memandang yang digunakan dalam sebuah kalimat: Dia jangan dipandang; Dia meman-dang langit biru.

Dari tiga sumber pantun yang diteliti, PM dan PMB terdapat dalam kategori ini, sedangkan PP tidak. Tidak adanya PP dalam kategori ini disebabkan oleh penciptaannya lebih berorientasi pada salah satu ciri yang dianggap utama, yaitu kesamaan bunyi atau rima akhir larik a, b, 
Hidayatul Astar: Konstruksi Sepadan dan Tak Sepadan antara Larik...

a, b. Pemantun atau penulis pantun tidak menggunakan konsep formula seperti pantun tua atau klasik Melayu.

Pantun berkonstruksi sepadan penuh ini merupakan pantun yang baik karena, selain sepadan dari sisi aspek bahasa yang diteliti, ciri umumnya telah terpenuhi dan rimanya pun tidak hanya pada posisi akhir. Keberadaan rima pada posisi selain akhir ini disebabkan oleh penggunaan konsep formula dalam bentuk pengulangan kata dan bunyi dalam batas suku kata.

\subsection{Konstruksi Sepadan Sebagian}

Konstruksi larik sampiran dan larik isi pantun (6)-(11) berikut sepadan sebagian karena jumlah unsur salah satu pasangan larik yang diperbandingkan tidak sama. Dalam pantun (6) dan (7) jumlah unsur larik yang tak sepadan terdapat antara larik antara S-1 dan I-1, sedangkan dalam pantun (8)-(10) jumlah unsur tak sepadan terdapat antara larik S-2 dan I-2. Larik yang memiliki jumlah unsur yang tidak sama atau lebih banyak dari larik lain disebabkan oleh jumlah klausa yang tidak sama. Larik S-1 dan I-1 atau S-2 dan I-2 yang sepadan ditandai pula oleh kesepadanan dan ketidaksepadanan jumlah kata, fungsi sintkasis, susunan unsurnya, dan jenis kalimatnya.

Dalam pantun (6) berikut ini jumlah unsur yang tidak sama terdapat antara larik S-1 dan I-1. S-1 terdiri atas dua unsur, sedangkan I-1 empat unsur. S-2 dan I-2 sama-sama tiga unsur. Unsur pertama dan kedua larik S-2 dan I-2 samasama terdiri atas satu kata, sedangkan unsur ketiga tidak sama, tiga dan satu.

(6) Burung balam// terbang melayang

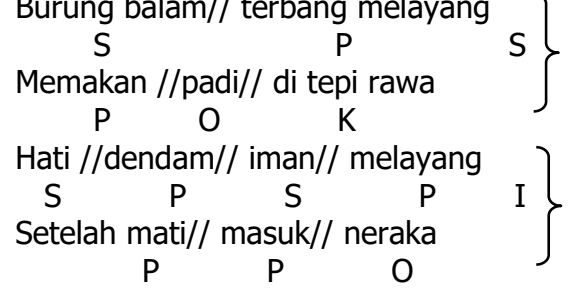
(PMB)

Dua unsur larik ganjil pantun tersebut menduduki fungsi $S$ dan $P$ dan yang empat unsur menduduki fungsi $S, P, S$, dan $P$. Tiga unsur larik genap memiliki menduduki fungsi yang tidak sama, yaitu $\mathrm{P}, \mathrm{O}$, dan $\mathrm{K}$ (S-2) dan $\mathrm{P}, \mathrm{P}$, dan $\mathrm{O}$ (I-2). Baik unsur larik ganjil maupun unsur larik genap dalam susunan biasa. Subjek dalam S-2 dan I-2 yang diimplisitkan mendahului predikat: (burung balam) memakan...; setelah (kita) mati....

Larik sampiran dan larik isi pantun tersebut berjenis kalimat tidak sama. Larik sampiran merupakan sebuah kalimat majemuk setara, sedangkan larik isi merupakan dua kalimat majemuk bertingkat. Secara keseluruhan ada tiga kalimat yang membangun pantun tersebut, yaitu sebagai berikut.
a. Burung balam terbang melayang, lalu memakan padi di tepi rawa (sampiran).
b. Kalau hati kita dendam, iman kita melayang (I-1).
c. Setelah kita mati, masuk neraka. (I-2)

Jumlah unsur yang berbeda dalam pantun (7) berikut juga terdapat dalam larik S-1 dan I-1. S-1 terdiri atas tiga unsur, sedangkan I-1 empat unsur. S-2 dan I-2 sama-sama tiga unsur. Kesepadanan jumlah unsur larik S-2 dan I2 juga didukung oleh kesepadanan jumlah kata per unsurnya. Unsur pertama yang menepati fungsi $\mathrm{S}$ sama-sama satu kata, unsur kedua yang menepati fungsi $P$ samasama satu kata, dan unsur ketiga yang menempati fungsi Pel. dan K sama-sama terdiri atas dua kata.

(7) Ayam hutan// terbang// ke hutan

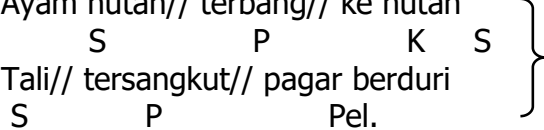

$$
\begin{aligned}
& \text { Adik //bukan// saudara// bukan }
\end{aligned}
$$

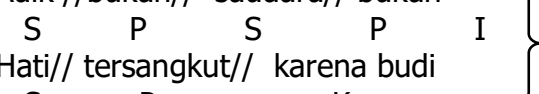

$$
\begin{aligned}
& \mathrm{S} \quad \mathrm{P} \quad \mathrm{K} \\
& \text { (PM) }
\end{aligned}
$$

Tiga unsur larik ganjil pantun tersebut juga menduduki fungsi yang berbeda, yaitu S, P, dan K (S-1) dan S, P, dan Pel. (I-1). Tiga unsur larik S-2 menduduki fungsi $S, P$, $\mathrm{S}$, dan $\mathrm{P}$ dan larik I-2 menduduki fungsi $\mathrm{S}$, $P$, dan K. Baik susunan unsur larik ganjil dan larik genap juga sama-sama dalam susunan biasa.

Dua larik sampiran dan dua larik isi pantun tersebut juga tidak sepadan jenis kalimatnya. Dua larik sampiran merupakan kalimat tunggal sendiri-sendiri dan tidak berhubungan. Sementara itu, larik isi 
Hidayatul Astar: Konstruksi Sepadan dan Tak Sepadan antara Larik...

merupakan sebuah kalimat majemuk setara. Isi pertama berasal tanya jawab: Dia adik? (tanya) Bukan. (jawaban); Dia saudara? (tanya) Bukan. (jawab). Larik isi kedua merupakan lanjutan infromasi larik isi pertama, tetapi tidak menjadi satu kalimat.

Secara keseluruhan enam lima kalimat yang membangun pantun tersebut, yaitu sebagai berikut.
a. Ayam hutan terbang ke hutan.
b. Tali tersangkut pagar berduri.
c. Adik?
d. Saudara?
f. Bukan.
e. Hati tersangkut karena budi.

Dalam pantun (8) berikut ini jumlah unsur yang tidak sama terdapat antara larik S-2 dan I-2, sedangkan antar larik S-1 dan I-1 sama, yaitu sama-sama terbagi atas dua unsur. S-2 hanya terbagi atas satu unsur, sedangkan I-2 tiga unsur. Kesepadanan jumlah unsur larik S-1 dan I1 tidak didukung oleh kesepadanan jumlah kata per unsurnya. Unsur kedua yang menempati fungsi $\mathrm{S}$ dan $\mathrm{K}$ terdiri atas dua dan satu kata.

(8) Hang Jebat// Hang Kesturi

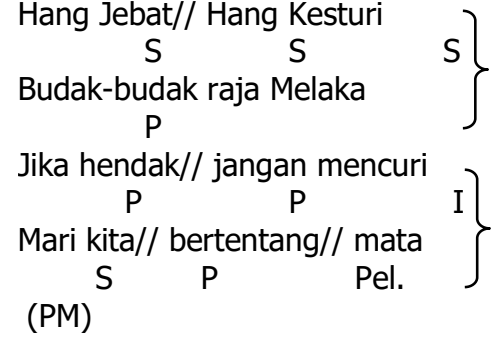

Dua unsur larik larik S-1 pantun tersebut menduduki fungsi $\mathrm{S}$ dan $\mathrm{S}$ dan dua unsur I-1 menduduki fungsi $K$ dan $P$. Satu unsur larik S-2 menduduki fungsi $P$ dan tiga unsur larik I-2 menduduki fungsi $S$, P, dan Pel. Baik susunan unsur larik ganjil dan larik genap juga sama-sama dalam susunan biasa. S-1 dan S-2 merupakan satu konstruksi klausa.

Larik sampiran dan larik isi pantun tersebut tidak sepadan dari sisi konstruksi kalimat. Larik sampiran merupakan sebuah kalimat tunggal. Larik sampiran pertama merupakan subjek dan larik sampiran kedua merupakan predikanya. Larik isi pertama merupakan kalimat majemuk bertingkat, sedangkan larik isi kedua merupakan kalimat tunggal. Konstruksi pantun tersebut berasal dari tiga kalimat berikut.

a. Hang Jebat Hang Kesturi budak-budak raja Melaka.

b. Jika hendak, jangan mencuri. (I-1).

c. Mari kita bertenang mata. (I-2)

Jumlah unsur yang tak sama dalam pantun (9) berikut juga terdapat antara larik S-2 dan I-2. S-2 terbagi atas dua unsur, sedangkan I-2 tiga unsur. S-1 dan I-1 sama-sama terbagi atas dua unsur. Kesepadanan jumlah unsur larik S-1 dan I1 tidak didukung oleh kesepadanan jumlah kata per unsurnya. Unsur kedua yang menepati fungsi $\mathrm{K}$ terdiri atas tiga dan dua kata.

(9)

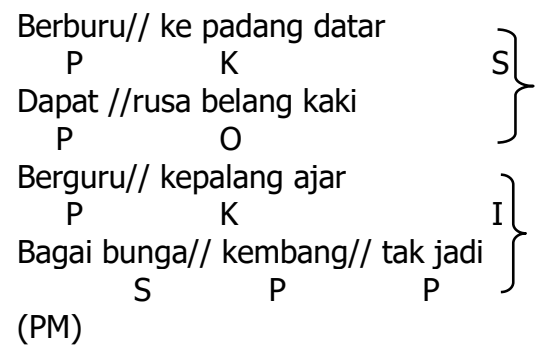

Dua unsur larik ganjil pantun tersebut menduduki fungsi yang sama, yaitu $P$ dan K. Dua unsur larik genap pertama (S-2) menduduki fungsi $P$ dan $O$ dan larik genap kedua (I-2) menduduki fungsi $\mathrm{S}, \mathrm{P}$, dan $\mathrm{P}$. Baik larik ganjil maupun larik genap dalam susunan biasa karena subjek dalam S-2 dan I-2 yang diimplisitkan mendahului predikat: (saya) berburu...; (saya) dapat...; (kita) berguru....

Larik sampiran dan larik isi pantun tersebut sepadan konstruksi kalimatnya karena sama-sama dalam jenis kalimat majemuk bertingkat tanpa konjungsi yang eksplisit. Kedua larik sampiran dan isi pantun itu dapat diubah menjadi dua kalimat berikut.

a. Ketika berburu kepada datar, kami mendapat rusa belang kaki.

b. Ketika berguru kepalang ajar, itu bagai bunga kembang tak jadi.

Jumlah unsur yang berbeda dalam pantun (10) berikut juga terdapat antara larik S-2 dan I-2. Larik S-2 terdiri atas dua unsur, sedangkan I-2 empat unsur. Larik S-1 dan I-1 sama-sama terbagi atas tiga 
Hidayatul Astar: Konstruksi Sepadan dan Tak Sepadan antara Larik...

unsur. Kesepadanan jumlah unsur larik S-1 dan I-1 tidak didukung oleh kesepadanan jumlah kata per unsurnya. Unsur pertama yang menepati fungsi $\mathrm{S}$ dan $\mathrm{K}$ terdiri atas dua dan satu kata.

$$
\begin{aligned}
& \text { (10) Jenderal majlis// mati// di Bali }
\end{aligned}
$$

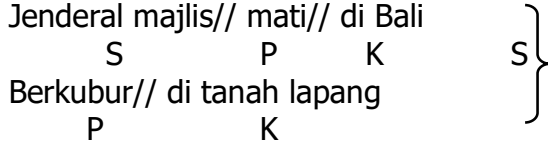

$$
\begin{aligned}
& \text { Apa// diharap// kepada kami } \\
& \left.\begin{array}{lccc}
\mathrm{P} & \mathrm{S} & \mathrm{K} & \mathrm{I} \\
\mathrm{Emas} & / / \text { tiada// } & \text { bangsa } / / \text { pun } & \text { kurang } \\
\mathrm{S} & \mathrm{P} & \mathrm{S} & \mathrm{P}
\end{array}\right\} \\
& \text { (PM) }
\end{aligned}
$$

Tiga unsur larik ganjil pantun tersebut menduduki fungsi yang sama, yaitu $S, P$, dan $K$, tetapi berbeda urutan. Dua unsur larik $\mathrm{S}-2$ menduduki fungsi $\mathrm{P}$ dan $\mathrm{K}$ dan larik I-2 menduduki fungsi $S, P, S$, dan $P$. Unsur larik ganjil dalam susunan biasa (S1) dan inversi (I-1), sedangkan larik genap sama-sama dalam susunan biasa. Subjek yang diimplisitkan dalam S-2 mendahului predikat: (jenderal majlis) berkubur....

Larik sampiran dan larik isi pantun tersebut tak sepadan jenis kalimatnya. Larik sampiran merupakan satu kalimat majemuk setara, sedangkan larik isi merupakan satu kalimat majemuk bertingkat dan setara atau campuran. Larik sampiran dan isi pantun tersebut dapat diubah menjadi dua kalimat kalimat berikut.

a. Jenderal majlis mati di Bali dan berkubur di tanah lapang.

b. Apa diharap kepada kami karena emas tiada dan bangsa pun kurang.

Jumlah unsur yang berbeda dalam pantun (11) berikut juga terdapat dalam larik S-2 dan I-2. Larik genap pertama (S2) terdiri atas dua unsur, sedangkan larik genap kedua (I-2) empat unsur. Larik ganjil pertama (S-1) dan larik ganjil kedua (I-1) sama-sama tiga unsur. Kesepadanan jumlah unsur larik S-1 dan I-1 tidak didukung oleh kesepadanan jumlah kata per unsurnya. Unsur pertama yang menepati fungsi $\mathrm{P}$ dan $\mathrm{K}$ terdiri atas satu dan dua kata.

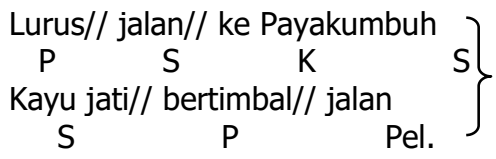

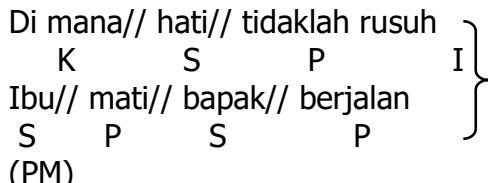

Tiga unsur larik ganjil pantun tersebut juga menduduki fungsi yang sama, yaitu $S$, $P$, dan $K$, tetapi berbeda urutan. Tiga unsur larik S-2 menduduki fungsi $\mathrm{S}, \mathrm{P}$ dan Pel. dan larik I-2 menduduki fungsi S, P, S, dan $P$. Baik unsur larik ganjil dan larik genap dalam susunan biasa.

Larik sampiran dan larik isi pantun tersebut juga tidak sepadan jenis kalimatnya. Konstruksi pantun ini mirip dengan konstruksi pantun (7) dan (11). Dua larik sampiran merupakan kalimat tunggal sendiri-sendiri dan tidak berhubungan. Sementara itu, larik isi merupakan sebuah kalimat majemuk bertingkat. Larik pantun tersebut terbagi tiga kalimat, yaitu sebagai berikut.

a. Lurus jalan ke Payakumbuh.

b. Kayu jati bertimbal jalan.

c. Di mana hati tidaklah rusuh karena ibu mati dan bapak berjalan.

Enam contoh pantun yang berkonstruksi sepadan sebagian tersebut umumnya tidak ditandai oleh adanya pengulangan kata seperti pada pantun (1)--(5). Pengulangan kata hanya terdapat dalam dalam pantun (6) dan (7). Kata yang berulang terdapat dalam S-1 dan I-1 saja dan antara S-2 dan I-2 dalam pantun (6), sedangkan dalam pantun (7) hanya terdapat dalam S-2 dan I-2. Dalam empat pantun berikutnya, (8), (9), (10), (11) tidak menggunakan konsep formula. Walaupun antarsampiran dan isi dapat dijadikan satu konstruksi kalimat, jenis kalimat dan strukturnya tidak sama seperti terlihat pada pantun (9) dan (10). Sampiran kedua pantun itu terdiri atas dua kalimat dasar, sedangkan isi terdiri atas tiga kalimat dasar. Selanjutnya, kalimat ubahan pantun (6), (7), (8) dan (11) lebih dari dua, yaitu 3, 6, 3, dan 3 .

Karena penggunaan konsep formula tidak seperti pantun berkategori sepadan penuh, kata yang digunakan dalam pantun berkonstruksi sepadan sebagian lebih variatif atau lebih banyak daripada pantun berkonstruksi sepadan penuh. Perbandingan kata pantun (1) dan (6) berikut membuktikan kevariatifannya. 
Hidayatul Astar: Konstruksi Sepadan dan Tak Sepadan antara Larik...

$\begin{array}{ll}\text { Pantun (1): } & \begin{array}{l}\text { tuailah, intailah, padi, kami, } \\ \text { antara, masak, esok, nampak, } \\ \text { jangan, layu-layuan, rindu-rinduan }\end{array} \\ \text { (11 kata). } \\ \text { Pantun (6): } \begin{array}{l}\text { burung, balam, terbang, } \\ \text { melayang, memakan, padi, di, } \\ \text { tepi, rawa, hati, dendam, iman, } \\ \text { setelah, mati, masuk, neraka (16 } \\ \text { kata) }\end{array}\end{array}$

Dari enam pantun itu juga tidak ada PP. Ini menandakan bahwa PP hanya dalam kategori pantun berkonstruksi tak sepadan. Penyebabnya sama dengan yang sudah disebutkan dalam seksi 3.2 paragraf akhir, yaitu penciptaannya lebih berorientasi pada rima akhir a, b, a, b, dan tidak menggunakan formula.

Pantun berkonstruksi sepadan sebagian ini juga merupakan pantun yang baik. Ini ditandai pula oleh ciri umum yang sudah terpenuhi dan adanya formula dan rima pada posisi selain posisi akhir larik pada pantun tertentu. Variasi kata yang lebih banyak dengan kesamaan bunyi dalam batas suku kata di posisi awal dan tengah larik salah satu kekhasan pantun kategori dua ini.

\subsection{Konstruksi Tak Sepadan}

Konstruksi pantun (12)-(16) berikut tak sepadan karena jumlah unsur antara larik S-1 dan I-1 tidak sama dan antara larik S-2 dan I-2 juga tidak sama. Berdasarkan data, ditemukan lima komposisi ketaksepadan antarlarik ganjil dan genap pantun, yaitu komposisi (a) $2: 4$ dan $3: 2$, (b) $3: 4$ dan $2: 4$, (c) $2: 3$ dan $4: 2$, (d), $4: 3$ dan $3:$ 2 , dan (e) $4: 3$ dan $4: 1$. Jumlah unsur yang berbeda dalam sebuah pantun terdapat dalam konstruksi sama-sama satu atau dua klausa, konstruksi tidak sama, satu dan dua klausa, dan konstruksi tidak sama, klausa dan frasa.

Pantun (12) berikut ini memperlihatkan ketaksepadanan komposisi (a). Larik S-1 terdiri atas dua unsur dalam satu klausa, sedangan I-1 empat unsur dua dalam dua klusa; larik S-2 terdiri atas tiga unsur dalam satu klausa, sedangkan I-2 dua unsur dalam satu klausa.

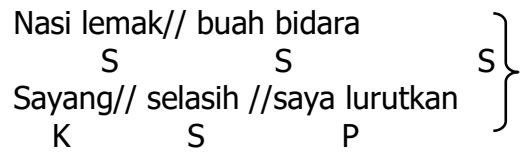

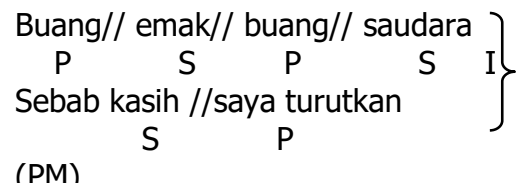

Dua unsur larik larik S-1 menduduki fungsi $S$ dan $S$ dan empat unsur I-1 menduduki fungsi $\mathrm{P}, \mathrm{S}, \mathrm{P}$, dan $\mathrm{S}$; Tiga unsur larik $\mathrm{S}-2$ menduduki fungsi $\mathrm{K}, \mathrm{S}$, dan $P$ dan dua unsur larik I-2 menduduki fungsi $S$ dan P. Susunan unsur larik ganjil dalam susunan tidak sama, yaitu susunan biasa (S-1) dan inversi (S-1), sedangkan susunan unsur larik genap sama-sama dalam susunan biasa.

Larik sampiran dan larik isi pantun tersebut juga tidak sepadan jenis kalimatnya. Konstruksi pantun ini mirip dengan konstruksi pantun (7) dan (11). Dua larik sampiran merupakan kalimat tunggal sendiri-sendiri dan tidak berhubungan. Sementara itu, larik isi merupakan sebuah kalimat majemuk bertingkat yang ditandai oleh konjungsi sebab. Pantun tersebut juga terbagi atas tiga kalimat, yaitu sebagai berikut.

a. Nasi lemak buah bidara.

b. Sayang selasih saya lurutkan.

c. Buang emak buang saudara sebab kasih saya turutkan.

Pantun (13) berikut ini memperlihatkan ketaksepadanan komposisi (b). Larik S-1 terdiri atas tiga unsur dalam dua klausa, sedangan I-1 empat unsur dalam dua kluasa; larik S-2 terdiri atas dua unsur dalam satu klausa, sedangkan I-2 empat unsur dalam dua klausa.

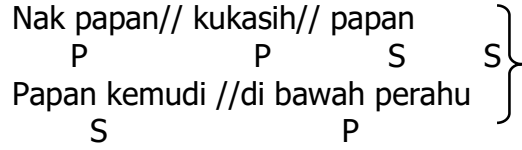

$$
\begin{aligned}
& \text { Disuruh// makan// aku// makan }
\end{aligned}
$$

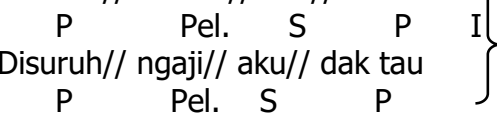

$$
\begin{aligned}
& \text { (PMB) }
\end{aligned}
$$

Tiga unsur larik S-1 menduduki fungsi $P, P$, dan $S$ dan empat unsur I-1 menduduki fungsi $\mathrm{P}$, Pel., $\mathrm{S}$, dan P; Dua unsur larik $S-2$ menduduki fungsi $S$ dan $P$ dan empat unsur larik I-2 menduduki fungsi P, Pel., S, dan P. Susunan unsur larik ganjil dalam susunan tidak sama, 
Hidayatul Astar: Konstruksi Sepadan dan Tak Sepadan antara Larik...

yaitu susunan biasa dan inversi (S-1) dan biasa (I-1), sedangkan susunan unsur larik genap sama-sama dalam susunan biasa. Subjek yang dieksplisitkan dalam S-1, I-1, dan I-2 mendahului predikat: (dia) nak papan; (aku) disuruh makan; (aku) disuruh ngaji.

Larik sampiran dan larik isi pantun tersebut juga tidak sepadan jenis kalimatnya. Konstruksi pantun ini mirip dengan konstruksi pantun (7), (11), dan (13). Dua larik sampiran merupakan kalimat majemuk (S-1) dan tunggal (S-2). Kedua sampiran tidak berhubungan walaupun ada pengulangan kata papan dalam dua larik tersebut. Sementara itu, larik isi merupakan masing-masing satu kalimat majemuk bertingkat. Pantun tersebut terbagi atas empat kalimat berikut.
a. Nak papan, kukasih papan.
b. Papan kemudi di bawah perahu.
c. Ketika disuruh makan, aku makan.
d. Ketika disuruh ngaji, aku dak tau.

Pantun (14) berikut ini memperlihatkan ketaksepadanan komposisi (c). Larik S-1 terdiri atas dua unsur dalam satu klausa, sedangan I-1 empat unsur dalam dua klausa; larik S-2 terdiri atas tiga unsur dua klausa, sedangkan I-2 dua unsur dalam satu klausa.

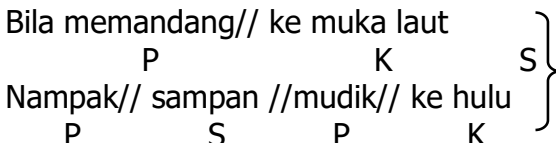

$$
\begin{aligned}
& \text { Bila terkenang// mulut// menyebut } \\
& \text { Budi yang baik// ingat selalu } \\
& \text { (PM) } \\
& \mathrm{S} \\
& P
\end{aligned}
$$

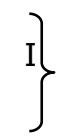

Dua unsur larik S-1 menduduki fungsi $P$ dan $\mathrm{K}$ dan tiga unsur I-1 menduduki fungsi $\mathrm{P}, \mathrm{S}$, dan $\mathrm{P}$; empat unsur larik S-2 menduduki fungsi $\mathrm{P}, \mathrm{S}, \mathrm{P}$, dan $\mathrm{K}$ dan dua unsur larik I-2 menduduki fungsi $S$ dan $P$. Susunan tiap unsur larik ganjil dalam susunan biasa (S-1), sedangkan larik genap S-2 dalam susunan inversi dan biasa dan I-2 dalam susunan biasa.

Larik sampiran dan larik isi pantun tersebut merupakan satu kalimat yang berjenis sama, yaitu majemuk bertingkat yang ditandai konjungsi bila. Dalam larik isi terdapat konjungsi yang diimplisitkan, yaitu bahwa. Kontruksi sampiran dan isi dapat diubah menjadi dua kalimat berikut.

a. Bila memandang ke muka laut, nampak sampan mudik ke hulu.

b. Bila terkenang, mulut menyebut bahwa Budi yang baik ingat selalu.

Pantun (15) berikut ini memperlihatkan ketaksepadanan komposisi (d). Larik S-1 terdiri atas empat unsur dalam dua klausa, sedangan I-1 dua unsur satu klausa; larik S-2 terdiri atas tiga unsur dalam dua klausa, sedangkan I-2 dua unsur dalam satu klausa.

$$
\begin{aligned}
& \begin{array}{ccc}
\text { Pergi// ke pasar //naik// ojek } \\
\mathrm{P}
\end{array} \mathrm{K} \quad \mathrm{P} \quad \mathrm{O} \\
& \text { Tidak lupa// membeli// cangkul } \\
& P \\
& \mathrm{P}
\end{aligned}
$$

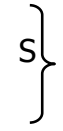

Empat unsur larik S-1 menduduki fungsi $\mathrm{P}, \mathrm{K}, \mathrm{P}$, dan $\mathrm{O}$ dan dua unsur $\mathrm{I}-1$ menduduki fungsi $\mathrm{S}, \mathrm{P}$, dan $\mathrm{O}$; Tiga unsur larik S-2 menduduki fungsi $\mathrm{P}, \mathrm{P}$, dan $\mathrm{O}$ dan dua unsur larik I-2 menduduki fungsi $P$ dan O. Baik unsur larik ganjil maupun larik genap dalam susunan yang sama, yaitu susunan biasa. Subjek yang dieksplitkan dalam S-1, S-2, dan I-2 mendahului predikat: (saya) pergi ke pasar; (saya) naik ojek; demi (Nadiem Makarim) mengabdi go school.

Larik sampiran dan larik isi pantun tersebut tidak sepadan jenis kalimatnya. Dua larik sampiran merupakan kalimat sendiri-sendiri. Larik S-1 merupakan kalimat majemuk betingkat tanpa konjungsi eksplisit, sedangkan larik S-2 kalimat tunggal. Sementara itu, larik isi merupakan satu kalimat majemuk bertingkat. Pantun tersebut terbagi atas tiga kalimat berikut.

a. Ketika pergi ke pasar, saya naik ojek.

b. Saya tidak lupa untuk membeli cangkul.

c. Nadiem Makarim meninggalkan Gojek demi mengabdi go school.

Pantun (16) berikut ini memperlihatkan ketaksepadanan komposisi (e). Larik S-1 terdiri atas empat unsur dalam dua klausa, 
Hidayatul Astar: Konstruksi Sepadan dan Tak Sepadan antara Larik...

sedangan I-1 tiga unsur dalam satu klausa; larik S-2 terdiri atas empat unsur dalam dua klausa, sedangkan I-2 satu unsur hanya dalam batas frasa.

(16) Menyeberang//sungai//memakai//sampan

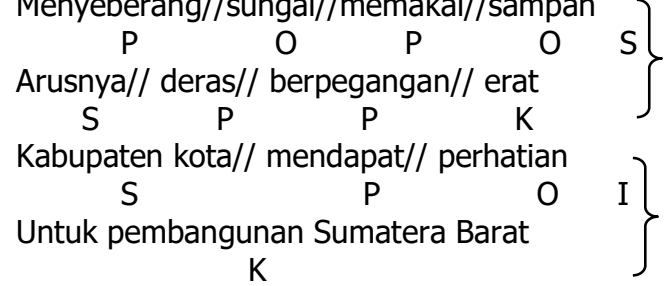
(PP)

Empat unsur larik S-1 menduduki fungsi $\mathrm{P}, \mathrm{O}, \mathrm{P}$, dan $\mathrm{O}$ dan tiga unsur $\mathrm{I}-1$ menduduki fungsi $\mathrm{S}, \mathrm{P}$, dan $\mathrm{O}$; empat unsur larik S-2 menduduki fungsi $S, P, P$, dan $\mathrm{K}$ dan satu unsur larik I-2 menduduki fungsi K. Baik susunan unsur larik ganjil maupun larik genap dalam susunan biasa. Subjek dalam S-1 yang dieksplisitkan pada posisi mendahului predikat: (kami) menyebarang sungai; (kami) memakai sampan; kami berpegangan erat. I-2 merupakan bagian dari I-1.

Konstruksi larik sampiran dan larik isi pantun tersebut tidak sepadan jenis kalimatnya. Konstruksi pantun ini mirip dengan konstruksi pantun (15). Dua larik sampiran masing-masing merupakan kalimat majemuk bertingkat. Sementara itu, larik isi merupakan satu kalimat tunggal. Pantun tersebut terbagi atas tiga kalimat berikut.

a. Ketika menyeberang sungai, kami memakai sampan.

b. Karena arusnya deras, kita berpegangan erat.

c. Kabupaten kota mendapat perhatian untuk pembangunan Sumatra Barat.

Lima contoh pantun yang berkonstruksi tak sepadan tersebut umumnya juga ditandai oleh adanya pengulangan yang juga tidak seperti pada pantun (1)--(5). Pengulangan kata hanya terdapat dalam pantun (12), (13), dan (14). Konsep formula dalam pantun kategori tiga ini tidak hanya antara sampiran dan isi, tetapi juga antarisi dan dalam satu larik.

Seperti pada pantun berkontsruksi sepadan sebagian, satu kalimat sampiran dan satu kalimat isi setelah diubah memperlihatkan strukturnya tidak sama seperti terlihat pada pantun (14). Sampiran terdiri atas dua kalimat dasar, sedangkan isi terdiri atas tiga kalimat dasar. Selanjutnya, kontruksi kalimat pantun (12), (13), (15) dan (16) selalu 3.

Karena umumnya tidak menggunakan konsep formula seperti dalam pantun berkonstruksi sepadan penuh, kata yang digunakan dalam enam pantun tersebut juga lebih variatif seperti halnya pantun berkontruksi sepadan sebagian. Kata yang digunakan dalam setiap larik berbeda-beda dan umunya tanpa ada bunyi yang sama selain yang di akhir baris.

Pantun berkonstruksi tak sepadan terdapat dalam tiga sumber pantun yang diteliti. Ini menandakan bahwa pantun dalam kategori tak sepadan konstruksi ini lebih banyak tercipta daripada yang berkonstruksi sepadan penuh dan sepadan sebagian. Pantun kategori ini dianggap lebih mudah tercipta karena hanya menguta-makan kesamaan bunyi akhir saja seperti terlihat dalam PP.

Pantun berkonstruksi tak sepadan ada yang tergolong baik dan ada kurang baik. Pantun (12) dan (13) tergolong baik, sedangkan pantun (14)-(16) tergolong kurang baik. Indikator kebaikan itu terasa ketika pantun tersebut didengar atau dibaca. Di sini terlihat ketidaksepadan unsur berpengaruh terhadap pantun yang baik. Perbedaan jumlah unsur yang lebih dari satu antara salah satu larik sampiran dan isi akan terasa janggal atau tidak lazim dalam hal ini. Walaupun semua ciri umum terpenuhi dalam semua pantun, PM dan PMB ada yang baik dan ada yang kurang baik, PP tergolong kurang baik.

\section{SIMPULAN}

Konstruksi pantun berdasarkan perbandingan jumlah unsur antara larik S-1 dan I1 dan antara larik S-2 dan I-2 terbagi tiga, yaitu (1) pantun berkonstruksi sepadan penuh, (2) pantun berkonstruksi sepadan sebagian, dan (3) pantun berkonstruksi tak sepadan. Pantun berkonstruksi sepadan sebagian lebih banyak daripada pantun berkonstruksi sepadan penuh dan tak sepadan. Adanya tiga kategori konstruksi ini berkaitan dengan proses kreatif dari seorang pemantun atau penulis pantun. Kategori ini juga menggambarkan perbe- 
Hidayatul Astar: Konstruksi Sepadan dan Tak Sepadan antara Larik...

daan cara berpantun atau menulis pantun antara pemantun atau penulis pantun yang satu dan yang lain. Pemantun yang satu sangat mementingkan keteraturan yang ketat sehingga pantunnya berkategori sepadan penuh dan pemantun yang lain tidak demikian sehingga pantunnya berkategori sepadan sebagian atau tak sepadan.

Tiga kategori konstruksi pantun yang ditemukan tersebut dapat memberi gambaran adanya tiga kategori orientasi pemantun atau penulis pantun ketika menciptakan sebuah pantun, yaitu (1) berorientasi pada kesepadan penuh, (2) berorientasi pada kesepadan sebagaian, dan (3) berorientasi pada tak sepadan. Pemi-lihan orientasi ini akan mengarah ke kesu-litan dan kemudahan penciptaan pantun. Pantun berkonstruksi sepadan dianggap le-bih sulit menciptakannya daripada sepadan sebagian atau tak sepadan karena peman-tun harus memadankan jumlah kata, jumlah unsur, fungsi sintaksis, dan susunan unsur jika tanpa formula dan tidak terbiasa berpantun. Sebaliknya, pantun tak sepadan lebih mudah menciptakannya daripada pantun sepadan penuh dan sepadan sebagian karena umumnya hanya berorientasi pada rima akhir dan tidak mempertimbangkan kesepadan dan formula.

Konstruksi pantun yang baik atau sesuai dengan konsep keindahan bahasa atau keteraturan susunan katanya harus menjadi acuan bagi para pemantun atau penulis pantun, khususnya bagi pemula atau yang belum terbiasa berpantun. Jangan sampai pantun yang tercipta tidak sesuai dengan konsep awal sebagai sebuah pantun. Ciri-ciri umum pantun yang telah ditemukan para peneliti pantun menjadi pegangan utama ketika akan berpantun atau menulis pantun. Jangan sampai ada pantun yang salah satu pasangan lariknya sangat berbeda dari sisi jumlah suku kata, jumlah kata, jumlah unsur, dan susunan unsur sehingga terasa janggal ketika didengarkan atau dibaca. Pantun seperti itu tercipta karena pemantun hanya berorientasi ke rima akhir baris sehingga tidak membatasi jumlah kata per larik dan tidak lagi sesuai dengan ciri umum pantun.
Sampiran dan isi sebuah pantun pada dasarnya berasal dari dua kalimat atau lebih. Jika bersal dari dua kalimat, sampiran dan isi umumnya berupa kalimat majemuk. Jika lebih dari dua kalimat, umumnya berjenis tunggal dan majemuk.

\section{DAFTAR PUSTAKA}

Alwi, Hasan et.al. 2017. Tata Bahasa Baku Bahasa Indonesia. Jakarta: Badan Pengembangan dan Pembinaan Bahasa.

Agustina, Rini dan Dea Amalia. 2016. "Analisis Struktur Fisik Dalam Pantun Dan Budaya Adat Istiadat dan Tata Cara Perkawinan Kabupaten Sambas Karya Hamdan Simad Dan Muhanni Abdur". Lingua. Vol. XII, No. 1, 1-12.

Amin, Md. Salmah. Koleksi Pantun Melayu Klasik. 2012.[https://www.slideshare. net/ salmahmdamin/koleksi-pantunmelayu-klasik], diakes, Rabu, 15 Mei 2019 pkl. 11.20

Amirlah, Jeni. 2012. Pantun Melayu. [ https://amirlahjeni.wordpress.com/20 12/04/20/pantun-melayu-4/ ] diunduh, Senin, 20 Mei 2019, pkl 12.36

Amrullah, Amri. 2018. "Susi, Somad, Sandi, dan Basuki Berpantun Jenaka Tanpa Sara".

[https://www.republika.co.id/berita/na sional/tokoh

perubahan/18/04/11/p6zulu 384-susisomad-sandi-dan-basuki-ber-pantunjenaka-tanpa-sara], diakses Senin, 5 November 2018 pkl. 13.16.

Andriani, Tuti. 2012. "Pantun dalam Kehidupan Melayu". Jurnal Sosial Budaya. Vol. 9, No. 2, 195--211.

Astar, Hidayatul. 2017. Bahasa Pantun Bangka. Yogyakarta: Azzagrafika.

Astar, Hidayatul. 2019. "Model Pantun Ditinjau dari Kesepadanan Struktur Kalimat Dasarnya". Gramatika. Vol. 7, No. 2, 115-125. 
Hidayatul Astar: Konstruksi Sepadan dan Tak Sepadan antara Larik...

Azemi, Pakde. 2011. Koleksi Pantun Melayu Klasik. [https://pakdeazemi.wordpress. com/2011/12/08/koleksi-pantunmelayu-klasik/ ] diunduh, Rabu 15 Mei 2019, pkl 14.02

CNN Indonesia. 2018. "Jurus 'Pantun' Jokowi Demi Raih Suara Pilpres di Sumatera".

[https://www.cnnindonesia.com/nasion al/20190406145017-32-383921/juruspantun-jokowi-demi-raih-suara-pilpresdi-sumatera] diakses, Jumat 12 April 2019 pkl. 10.24

Sedyawati, Edy et.al. 2004. Sastra Melayu Lintas Daerah. Jakarta: Pusat Bahasa Departemen Pendidikan Nasional.

Hendra. M. 2018. "25 Pantun Gubernur Sumatera Barat untuk Presiden Joko Widodo".[https://kumparan.com/langk anid/25-pantun-gubernur-sumbaruntuk-presiden-joko-widodo], diakses, Rabu 9 Januari 2019 pkl 10.30

Malau, Srihandriatmo. 2019. "Ketika Ketua Komisi X Buat Pantun Khusus untuk Nadiem, Kata Anggota Nggak Nyambung".

[ https://www.tribunnews.com/nasion al/2019/12/12/ketika-ketua-komisi-xbuat-pantun-khusus-untuk-nadiemkata-anggota-nggak-nyambung], diakses, Jumat, 13 Desember 2019 pkl. 14.12
Majod, Ali Mohamad. 2006. Pantun Budi Bahasa (Siri Koleksi Pantun Kanakkanak Bertema). Kuala Lumpur: Sanon Printing Corporation Sdn Bhd.

Liaw Yock Fang. 2013. A History of Classical Malay Literature. Jakarta: Yayasan Pustaka Obor Indonesia.

Rahman, Muhammad Azmi Ab. 2016. "Penjelmaan dan Penghayatan Asmaul Husna dalam Gunung Iman Puncak Takwa". Makalah Dialog Puncak Karyawan Angkatan Sasterawan Nasional Kedah (Asasi) 23 hingga 25 Disember.

Robins, R.H. 1991. Linguitik Umum sebagai Pengantar. Diterjemahkan oleh Superjati Jayanegara dari judul asli General Linguitics. Jakarta: Kanisius.

Gayatri, Satya. 2010. "Sistem Formula dan Fungsi Sastra Lisan Ronggeng Pasaman". Dalam Wacana Etnik. Vol. 1, Nomor 1, Aprik, 79--94.

Wiana, Desri. 2010. "Analisis Tema dalam Pantun Melayu (Suatu Kajian Fungsional Linguistik). Dalam Jurnal IImiah Abdi IImu. Vol. 3, Nomor 2, Desember, 384--391. 